\title{
Physicochemical characterization of milk, SueroCosteño and QuesoCosteño
}

\author{
Robert Valera Restrepo $^{\# 1}$, Luz Karina Corzo Pacheco ${ }^{\# 2}$, Piedad Margarita Montero astillo ${ }^{* 3}$, \\ Diofanor Acevedo Correa $^{* 4}$, Luis Alberto Gallo-García ${ }^{* 5}$ \\ \# Faculty of Engineering, Agroindustrial Engineering Program, Research GroupAgroindustrialOptimization - \\ Food and Environmental Management Integrated System (SIGAAL), Popular University of Cesar \\ * Faculty of Engineering, Food Engineering program, Research Group NUSCA, University of Cartagena Av. El \\ Consulado, St. 30 No. 48-152. Colombia. \\ 1'valerarestrepo56@hotmail.com; ${ }^{2}$ luzk1884@hotmail.com; ${ }^{3}$ pmargaritamontero@hotmail.com \\ 4diofanor3000@gmail.com; ${ }^{5} \operatorname{lgallog} 1992 @$ hotmail.com
}

\begin{abstract}
The objective of this study was to carry out the physical-chemical characterization of milk, suerocosteño and quesocosteño from the towns of Patillal, Badillo and La Vega. The milk produced in the Department of Cesar is transformed by family businesses located in rural areas without infrastructure, previous standardization processes and hygienic conditions. A physicochemical and chromatographic characterization was carried out in which the analysis of amino acids was included, first performing hydrolysis of the protein and derivation of the sample. Data were analysed using ANOVA analysis of variance and a minimum significant difference test (MSD). It was evidenced that milk and whey from Badillo were the ones that reported the highest protein content, $3.32 \%$ and $1.20 \%$ respectively. The results showed that Badillo reported the highest protein content for milk with $3.32 \%$ and whey $1.20 \%$, with Patillal cheese showing the highest percentage of essential amino acids such as isoleucine $31.28 \%$, tryptophan $34.92 \%$ and valine with $32.84 \%$. The amino acid content of suerocosteño and quesocosteño can be attributed to the production process, strength, rennet type and storage time.
\end{abstract}

Key words - physicochemical analysis, profile of amino acids, milk and whey.

\section{INTRODUCTION}

Milk is an ideal food in nutritional terms, it is composed on average of approximately $87.3 \%$ water, $4.2 \%$ fat, $4.6 \%$ lactose, $3.25 \%$ protein and mineral substances $0.65 \%$ [1]. This is why it is susceptible to microbial contamination, forcing the dairy industry to employ different processes to preserve its nutritional qualities [1]. From the physicochemical point of view, milk is a very complex and complete product containing all the nutrients such as protein, carbohydrates and lipids, indispensable for the individual, particularly the 10 essential amino acids: arginine, histidine, isoleucine, leucine, lysine, methionine, phenylalanine, threonine, tryptophan and valine[2]. The milk of the Department of Cesar is characterized physicochemically by its percentage of fat (4.3\%) and total solids (12.5 and 14\%), which is why multinational and regional companies have been located [3]. At present, there is a milk production of over $600.000 \mathrm{~L} \mathrm{day}^{-1}$, with a $50 \%$ decrease (Fedegan, 2016), which is distributed as follows: $52 \%$ is intended for formal processing; $43 \%$ is destined for the production of coastal cheese and 5\% for local consumption [3].

Emphasizing the "suerocosteño", is defined as a milk matrix fermented and commonly elaborated in the Colombian Atlantic Coast, produced by the acidification of raw milk, due to the action of the native microorganisms. It differs from the fermented milks because there is a break of the gel, the waste is produced and sodium chloride is added. The final product is similar to sour cream and is used as a companion. During the fermentation a system of two phases is formed: one liquid and one solid; where the liquid part is called whey and the other is known as "suero" [4]. The fermentation temperature of the "suerocosteño" is the most important factor in the growth of microorganisms, followed by the $\mathrm{pH}$, acidity and lactose obtained in the product [4].

Another derivative of the milk processing is cheese, which is defined as the product of the coagulation of casein in milk, followed by separation and removal of whey from the curd, is the generic name of a group of products fermented milk-based foods, produced in a wide range of flavours and shapes all over the world. Although the main purpose of making cheese is to conserve the main components of milk, which has evolved into a high-quality food with important qualities, as well as being very nutritious [5]. During the elaboration ofquesocosteño, several of the nutritive compounds like vitamins, proteins and milk fats are concentrated in a sub product that is the whey [6], the final fat content in the product is determined by the size of the fat globule, the kinetics of coagulation and the manipulation performed on the curd [7]. Likewise, the type of pasteurization used in the hygienization process influences the protein content of the cheeses, so the high temperatures favor the formation of a complex between the $\mathrm{K}$ casein and the $\mathrm{B}$ lactoglobulin that retains the proteins in the curd [8]. Taking into account the above, $43 \%$ of the production of quesocosteño is transformed by a guild that develops artisan practices established in rural areas without having a necessary infrastructure, without prior 
standardization of processes and quantification of yields. From this informal process is obtained approximately 4 to 6 tons in average of coastal cheese [3], being its main market place the city of Valledupar where the product is distributed to different market places and sales points to follow the distribution chain [3].

On the other hand, the methods that detect and quantify the amino acids, are of great interest for the food industry. Currently, reverse phase high performance liquid chromatography (HPLC) in combination with pre or post-column derivatization is the most widely used, "it is a separation technique in which the mixture to be solved is introduced into a system formed by a fluid (mobile phase), which circulates in contact with a phase which remains fixed or immobile during the process (stationary phase). In the case of liquid chromatography, the stationary phase is a solid or a liquid fixed in a solid and the mobile phase is a liquid. The two phases are chosen so that the components of the mixture are distributed differently between the mobile phase and the stationary phase. Those components that are strongly retained by the stationary phase move slowly with the flow of the mobile phase; on the other hand, the components that attach weakly to the stationary phase, move quickly. As a consequence of the different mobility, the components of the mixture are separated into discrete bands or zones that can be analysed qualitatively and/or quantitatively " [9]. Consequently, the amount of free amino acids in the cheese depends on the amount of milk proteins, the activity of proteolytic enzymes in dairy technologies and the microorganisms involved in these processes [10].

Multiple analytical methods have been developed for the quantification of amino acids in various biological matrices, including the combination of different chromatography techniques and various detection systems such as the amino acid analyzer by ion exchange chromatography Redruello et al., [10]. Researches as reported by Salmen et al.,[11], evaluated the amino acid content and the electrophoretic profile of casein in different bovine milks, reporting that the essential amino acids found in most of them were: lysine; 9.78 and leucine with 8.24 , followed by valine with 6.17 and threonine with $4.00 \mathrm{mg} 100 \mathrm{~g}^{-1}$. On the other hand, the non-essential amino acids detailed in the highest percentage were glutamic acid with 21.38 , followed by aspartic acid with 7.30 , serine 5.81 and tyrosine $4.97 \mathrm{mg} 100 \mathrm{~g}^{-1}$. Taurine and lysine, essential amino acids are considered essential nutrients for growth and development, taurine plays a key role in intestinal fat absorption and plays an important role in protecting neurons from oxidative stress [12]. The objective of this study was to physicochemicallycharacterizethe milk, Suero and QuesoCosteño from the townships of Patillal, Badillo and La Vega located in the Department of Cesar.

\section{MATERIALS AND METHODS}

To know the manufacturing process of suerocosteñoand quesocosteño from cow milk, a processing plant was visited for each township. From each township, three samples of different batches of $500 \mathrm{~mL}$ of milk and suerocosteño were taken, and $250 \mathrm{~g}$ of quesocosteño, obtained the same day of milking and elaboration, respectively. Samples were taken in triplicate, one per batch of production. These products were refrigerated at 4 ${ }^{\circ} \mathrm{C}$ individually in hermetic Styrofoam coolers and were taken to the Laboratories of Biology and Chemistry of the Popular University of Cesar for further analysis. These townships were selected because they are in the same northeastern area and because of their high production of suerocosteño and quesocosteño. For statistical analysis of the physicochemical characteristics, an experimental design was used in divided plots, where the plot was the type of township (Patillal, Badillo and La Vega) and the plot divided the type of product (milk, suerocosteño and QuesoCosteño).

\section{A Physicochemical properties}

The following physicochemical parameters were determined: density: by the gravimetric method [13] (925.22), the total nitrogen quantification Kjeldahlmethod(960.52), fat by the Gerber method (AOAC 2000.18), total solids by the modified stoving method (990.19) and ash: gravimetric method [14], all these tests were performed in triplicate [13].

\section{B Chromatographic analysis}

This analysis was performed on a high water liquid chromatograph, equipped with a Quaternary pump model 600E, a model 997 photodiode array detector (PDA), a model 717 automatic injector, and a reverse phase column (C-18) for analysis of amino acids PICO-TAG model 88131 of $3.9 \mathrm{~mm} \times 150 \mathrm{~mm}$. The data were processed by an NC power MATE 433 PC with millennium 2032 software, which was performed as follows: protein hydrolysis, pre-column sample derivation and reversible HPLC phase analysis. Separation of the amino acids was obtained by gradient elution at $38{ }^{\circ} \mathrm{C}$, using as a mobile phase the combination of effluents such as sodium acetate trihydrate $(19 \mathrm{~g})$, water $(1 \mathrm{~L})$, triethylamine $(\mathrm{TEA}, 0.5 \mathrm{~mL})$, acetonitrile $600 \mathrm{~mL})$ and $400 \mathrm{~mL}$ water. The total time of analysis and balance of the system was $20 \mathrm{~min}$ [15].

\section{A. Reaction of hydrolysis}

The acid hydrolysis process was carried out by treating the different samples; milk, Suerocosteñoand quesocosteño, with $\mathrm{HCl} 6 \mathrm{~N}$ and $1 \%$ phenol. To avoid reactions of tryptophan that might interfere with the result, 
a solution of $\mathrm{HCl} 7 \mathrm{M}$ : $10 \%$ trifluoro-acetic acid: $20 \%$ trichloroacetic acid and $1 \%$ phenol was used. These samples consisted of $10 \mu \mathrm{L}: 9.5 \mu \mathrm{L}$ of reagent and $0.5 \mu \mathrm{L}$ of sample. It was then transferred into a flask and wrapped with foil, each sample was brought to a heating plate for 24 hours [15].

\section{B. Derivation of the sample}

The resulting hydrolyzate was dried under vacuum to remove any impurities and a solution with ethanol, water and triethylamine (TEA) was added in a ratio of (2:2:1) respectively, this sample was again dried under vacuum and $7 \mu \mathrm{l}$ of a mixture of three solutions (OPA reagent), formulated as: ortho-phthalaldehyde, brij 35, methanol, 2-mercaptoethanol and potassium tetraborate, adjusted to a $\mathrm{pH}$ of 10.4 was added.

\section{Statistical analysis}

An analysis of variance (ANOVA) was carried out and the post hoc test of minimum significant difference (MSD) was applied, setting a level of significance at $p<0.05$ [16]. The results were expressed with their mean and standard deviation, using the statistical software package (Statgraphics Centurion 16.103, version 15.0, Chicago, USA). The number of samples per township was determined taking into account the total of analyses that were to be realized and the amount necessary according to previous investigations.

\section{RESULTS AND DISCUSSION}

\section{A. Physicochemical composition of milk, suerocosteño and quesocosteño}

Table 1 shows the results of the physicochemical characterization of the samples of milk, suerocosteño and quedocosteño obtained in the municipalities of Patillal, Badillo and La Vega. An objective observation was made of the conditions of processing of the unpasteurized type of cheese in each of the study areas. It was observed that Patillal lost about $84 \%$ of the protein content in whey during the production of suerocosteño, followed by Badillo with $63.85 \%$ and La Vega with $68 \%$. Regarding fat content, $84.34 \%$ of the Patillal district was eliminated in whey, $77.38 \%$ for Badillo and $72.56 \%$ La Vega. Studies conducted by Bertolino et al., [17] reported values of fat and protein of $23.9 \%$ and $19.5 \%$ in the elaboration of Roman pecorino cheese. Addis et al.,[18] reported that there were no significant differences in the moisture, fat and protein content with values of $33.19 \%, 47.83 \%$ and $39.25 \%$, respectively, using different types of rennet (animal, vegetal and enzymatic). Regarding the total solids, La Vega reported the lowest content of these compounds by $36.02 \%$. Non-fatty solids were only affected in Badillo and La Vega with $4.76 \%$ and $0.70 \%$ loss, during the production of suerocosteño. Regarding the cheese production, the group that concentrated the most protein was Patillal with $83.12 \%$, being superior that Badillo and La Vega in 7.05\% and 7.56\% respectively. The homogenization of the milk increases the retention of fat and moisture globules, due to the alteration of the structure of the clot. Some authors have stated that the casein / fat ratio of milk when it is close to 0.72 , produces better recovery of fat and protein in cheese, being maximum, in addition the addition of calcium chloride increases the yield of the cheeses [5].

Table 1. Physicochemical characterization of milk, suerocosteño and quesocosteño

\begin{tabular}{|c|c|c|c|c|c|c|c|c|c|}
\hline \multirow[t]{2}{*}{ Analysis } & \multicolumn{3}{|c|}{ Milk } & \multicolumn{3}{|c|}{ Suero costeño } & \multicolumn{3}{|c|}{ Queso costeño } \\
\hline & Patillal & Badillo & La Vega & Patillal & Badillo & La Vega & Patillal & Badillo & La Vega \\
\hline Density (g/L) & $1,026 \pm 0,15^{\mathrm{a}}$ & $1,028 \pm 0,17^{\mathrm{a}}$ & $1,028 \pm 0,26^{\mathrm{a}}$ & $1,023 \pm 0,42^{\mathrm{a}}$ & $1,026 \pm 0,14^{\mathrm{a}}$ & $1,024 \pm 0,42^{\mathrm{a}}$ & $1,025 \pm 0,25^{\mathrm{a}}$ & $1,022 \pm 0,19^{\mathrm{a}}$ & $1,029 \pm 0,14^{\mathrm{a}}$ \\
\hline Fat (\%) & $3,96 \pm 0,17^{\mathrm{a}}$ & $3,98 \pm 0,22^{\mathrm{a}}$ & $4,01 \pm 0,10^{\mathrm{b}}$ & $0,62 \pm 0,52^{\mathrm{a}}$ & $0,90 \pm 0,24^{\mathrm{b}}$ & $1,10 \pm 0,12^{\mathrm{c}}$ & $24 \pm 0,25^{\mathrm{a}}$ & $20 \pm 0,45^{\mathrm{b}}$ & $20 \pm 0,36^{\mathrm{b}}$ \\
\hline Ash $(g / 100 g)$ & $0,74 \pm 0,24^{\mathrm{a}}$ & $0,69 \pm 0,14^{b}$ & $0,69 \pm 0,26^{\mathrm{c}}$ & $0,50 \pm 0,10^{\mathrm{a}}$ & $0,36 \pm 0,37^{\mathrm{b}}$ & $0,42 \pm 0,35^{\mathrm{c}}$ & $2,81 \pm 0,14^{\mathrm{a}}$ & $2,90 \pm 0,83^{b}$ & $3,15 \pm 0,42^{c}$ \\
\hline $\begin{array}{l}\text { Non- } \\
\text { fatsolids (\%) }\end{array}$ & $8,24 \pm 0,28^{\mathrm{a}}$ & $8,59 \pm 0,28^{b}$ & $8,51 \pm 0,30^{b}$ & $8,24 \pm 0,20^{\mathrm{a}}$ & $8,18 \pm 0,47^{b}$ & $8,45 \pm 0,14^{\mathrm{c}}$ & $18,29 \pm 0,63^{\mathrm{a}}$ & $14,24 \pm 0,82^{b}$ & $29,28 \pm 0,14^{\mathrm{c}}$ \\
\hline
\end{tabular}

In the case of fat, Patillal cheese was the one that collected the more fat globules in $83.5 \%$, followed by Badillo and Vega with 4.07\% and 4.25\% less respectively. Likewise, La Vega obtained the highest amount of ash, total solids and non-fat solids, with Badillo and La Vega averaging $2.12 \%, 8.59 \%$ and $33.39 \%$, respectively. This could be due to the fact that the amount of rennet that was used in this township was more precisely dosed, controlling its use in comparison with Badillo and La Vega. The time of cutting and cheese disposal are relatively equal in all three townships and depends on the coagulation time, which was approximately 30 to 45 minutes. Abellán[8] reported values of total solids, fat and protein of $53.96 \%, 58.80 \%$ and $34.59 \%$, respectively, for the preparation of cheese obtained with natural coagulants in powder form. The content and composition of the fat exert a relevant influence on the quality of the cheese. Fat contributes to enhance the cheese texture, which is homogeneously distributed within the protein matrix Addis et al., [19]. These researchers reported a fat percentage of $47.9 \%$, protein $37.5 \%$ and ash $0.71 \%$ in semi-hard cheese. The fat 
content of the cheese is important because defines the consistency, the flavour, the aroma and the nutritive value of the cheese [20]. In fresh cheeses, high moisture content and low $\mathrm{pH}$ are conditions that affect texture and taste. The acidity in the cheese is another important factor that causes changes in the curd, having a correlation in the exit of humidity. During salting whatever the technique used, there is an exchange of matter between the curd and the phase in contact with the salt, causing a loss of water, organic substances and minerals. If there are more caseins in the middle, this forms a mesh, trapping more fat and other solids in the curd. On the other hand, the presence of somatic cells is an important source of enzymes, especially proteases, which correlate negatively with cheese yield, together with calcium concentration and $\mathrm{pH}$ decrease [5].

\section{B. Milk amino acid analysis}

Table 2 reports the results of the chromatographic analysis performed on milk, whey and coastal cheese, which detail the essential and non-essential amino acids found in the samples. These data are compared for each product of each township. It was evidenced that Patillal reported statistically significant differences $(p<0.05)$ in milk with the other two townships, among the following amino acids: isoleucine, valine and tyrosine $(\mathrm{p}<0.05)$, but between these two study areas no differences were found. Researches asreportedby Mazhitova et al., [21], studied the amino acid and fatty acid profile in Yegua's milk, reporting that the most abundant amino acids were glutamic acid (16.8-21.2\%), leucine (8.2-10.1\%) and lysine (8.9-10.1\%), these being very different from those of this study. Also Pappa et al.,[22] reported that cheeses that made with different types of milk, the concentration of amino acids showed a clear tendency to increase with maturation time, because during proteolysis, these compounds are released by proteolytic agents.

Table 2.Amino acid variation in milk, suerocosteño andquesocosteño in the townships.

\begin{tabular}{|c|c|c|c|c|c|c|c|c|c|}
\hline Analysis & Patillal & Badillo & La Vega & Patillal & Badillo & La Vega & Patillal & Badillo & La Vega \\
\hline Amino acids & Milk & Milk & Milk & Suero & Suero & Suero & Cheese & Cheese & Cheese \\
\hline Isoleucine & 年, & $7,45 \pm 0,28^{b}$ & $7,44 \pm 0,74^{\mathrm{b}}$ & $4,17 \pm 0,04^{\mathrm{a}}$ & $7,48 \pm 0,56^{\mathrm{b}}$ & $7,67 \pm 0,42^{b}$ & $27,75 \pm 0,32^{\mathrm{a}}$ & $0,18 \pm 0,01^{\mathrm{b}}$ & $0,16 \pm 0,74^{b}$ \\
\hline Leucine & $3,64 \pm 0,05^{\mathrm{a}}$ & $3,87 \pm 0,15^{\mathrm{a}}$ & $3,86 \pm 0,36^{\mathrm{a}}$ & $2,22 \pm 0,02^{\mathrm{a}}$ & $3,88 \pm 0,37^{\mathrm{b}}$ & $3,99 \pm 0,63^{b}$ & $12,05 \pm 0,25^{\mathrm{a}}$ & $0,09 \pm 0,026^{\mathrm{b}}$ & $1,12 \pm 0,67^{\mathrm{c}}$ \\
\hline Lysine & $4,08 \pm 0,06^{\mathrm{a}}$ & $4,22 \pm 0,13^{\mathrm{a}}$ & $4,27 \pm 0,72^{\mathrm{a}}$ & $2,53 \pm 0,08^{\mathrm{a}}$ & $3,88 \pm 0,47^{b}$ & $4,49 \pm 0,45^{\mathrm{c}}$ & $12,71 \pm 0,15^{\mathrm{a}}$ & $1,35 \pm 0,12^{b}$ & $2,39 \pm 0,43^{c}$ \\
\hline Metihonine & $7,42 \pm 0,05^{\mathrm{a}}$ & $8,10 \pm 0,47^{\mathrm{a}}$ & $8,00 \pm 0,78^{\mathrm{a}}$ & $4,14 \pm 0,07^{\mathrm{a}}$ & $8,05 \pm 0,23^{b}$ & $10,34 \pm 0,63^{\mathrm{c}}$ & $27,64 \pm 0,12^{\mathrm{a}}$ & $0,045 \pm 0,03^{\mathrm{b}}$ & $20,52 \pm 0,85^{\mathrm{c}}$ \\
\hline Phenylalanine & $8,76 \pm 0,06^{\mathrm{a}}$ & $9,00 \pm 0,14^{b}$ & $9,27 \pm 0,96^{\mathrm{c}}$ & $5,08 \pm 0,01^{\mathrm{a}}$ & $9,44 \pm 0,19^{b}$ & $9,73 \pm 0,41^{\mathrm{c}}$ & $31,28 \pm 0,1^{\mathrm{a}}$ & $3,70 \pm 0,063^{b}$ & $3,64 \pm 0,27^{b}$ \\
\hline Threonine & $3,78 \pm 0,07^{\mathrm{a}}$ & $4,01 \pm 0,25^{\mathrm{b}}$ & $3,81 \pm 0,85^{\mathrm{c}}$ & $0,24 \pm 0,09^{\mathrm{a}}$ & $4,07 \pm 0,45^{\mathrm{b}}$ & $4,07 \pm 0,23^{b}$ & $30,08 \pm 0,01^{\mathrm{a}}$ & $0,84 \pm 0,041^{b}$ & $2,10 \pm 0,36^{\mathrm{c}}$ \\
\hline Tryptophan & $10,870,08^{\mathrm{a}}$ & $11,36 \pm 0,31^{b}$ & $11,47 \pm 0,41^{\mathrm{b}}$ & $5,86 \pm 0,1^{\mathrm{a}}$ & $12,19 \pm 0,41^{\mathrm{b}}$ & $12,15 \pm 0,14^{b}$ & $34,92 \pm 0,06^{\mathrm{a}}$ & $4,65 \pm 0,023^{b}$ & $5,96 \pm 0,47^{\mathrm{c}}$ \\
\hline Valine & $6,09 \pm 0,05^{\mathrm{a}}$ & $6,71 \pm 0,21^{\mathrm{b}}$ & $6,50 \pm 0,36^{\mathrm{b}}$ & $2,23 \pm 0,03^{\mathrm{a}}$ & $6,61 \pm 0,28^{\mathrm{b}}$ & $6,38 \pm 0,45^{\mathrm{c}}$ & $32,84 \pm 0,04^{\mathrm{a}}$ & $0,82 \pm 0,06^{\mathrm{b}}$ & $12,6 \pm 0,23^{\mathrm{c}}$ \\
\hline \multicolumn{10}{|c|}{ Non-Essential Amino Acids } \\
\hline Tyrosine & $9,45 \pm 0,04^{\mathrm{a}}$ & $9,96 \pm 0,14^{b}$ & $9,90 \pm 0,12^{b}$ & $3,06 \pm 0,02^{\mathrm{a}}$ & $10,1 \pm 0,39^{b}$ & $9,87 \pm 0,74^{\mathrm{c}}$ & $54,35 \pm 0,08^{\mathrm{a}}$ & $4,90 \pm 0,04^{b}$ & $0,25 \pm 0,45^{\mathrm{c}}$ \\
\hline Arginine & $6,97 \pm 0,04^{\mathrm{a}}$ & $7,29 \pm 0,75^{\mathrm{b}}$ & $7,37 \pm 0,85^{\mathrm{b}}$ & $1,37 \pm 0,07^{\mathrm{a}}$ & $7,49 \pm 0,25^{\mathrm{b}}$ & $7,47 \pm 0,24^{b}$ & $47,67 \pm 0,02^{\mathrm{a}}$ & $1,61 \pm 0,08^{\mathrm{b}}$ & $0,86 \pm 0,45^{\mathrm{c}}$ \\
\hline Histidine & $6,48 \pm 0,06^{\mathrm{a}}$ & $6,90 \pm 0,36^{b}$ & $6,50 \pm 0,25^{\mathrm{a}}$ & $0,68 \pm 0,01^{\mathrm{a}}$ & $6,72 \pm 0,45^{\mathrm{b}}$ & $6,51 \pm 0,24^{\mathrm{c}}$ & $49,30 \pm 0,04^{\mathrm{a}}$ & $1,55 \pm 0,06^{\mathrm{b}}$ & $0,09 \pm 0,21^{\mathrm{c}}$ \\
\hline
\end{tabular}

The data indicate the mean $( \pm)$ with its respective standard deviation. Different letters in the same row indicate statistically significant differences $(\mathrm{p}<0.05)$.

\section{Suero costeño amino acidanalysis}

With regard to suerocosteño, the amino acids that had statistical differences among all townships were lysine, methionine, phenylalanine, valine, tyrosine and histidine. For the case of the suerocosteño, when the milk is acidified the physicochemical properties of the casein micelles are modified. If the $\mathrm{pH}$ decreases, the colloidal calcium $\mathrm{pH}$ of the micelles dissolves, causing a destabilization and release of the caseins to the medium. During proteolysis, casein and large peptides hydrolyze, resulting in the formation of intermediate sized peptides, which are hydrolyzed to form small peptides and free amino acids. This casein hydrolysis occurs due to the presence of residual plasmine which maintains a large part of its activity after the heat treatments of pasteurization. The levels of casein can be reduced by the effect of plasmine and residual rennet, together with the proteolytic activity of microorganisms present in milk as Enterococcus [23].

\section{Cheese amino acid analysis}

Emphasizing cheese amino acids, only the isoleucine and phenylalanine of Patillal had differences with Badillo and La Vega, the other amino acids had statistical differences between each others. The concentrations of the different amino acids in cheese are related to the manufacturing technology (type of curd, maturation 
conditions), duration of maturation and the degree and type of proteolysis, this is the most complex and the most biochemical event important during maturation [22].

On the other hand, the non-essential amino acids that predominated most in Patillal cheese were: tyrosine, arginine and histidine, being on average greater than the other amino acids from the other two municipalities in $95.26 \% ; 97.4 \%$ and $98.33 \%$ respectively. It is important that these amino acids are concentrated in the curd, because they are important in the development of aromas and texture in cheeses. Researchers have argued that the most relevant cause of nutrient loss was possibly due to the breakdown of the peptide bond in the chain of amino acids by the action of pepsin, which acts in a non-selective way by breaking the initial structure of the protein and hydrolysing it completely in the suerocosteño; as a result of this reaction, essential and non-essential amino acids are lost: as isoleucine, leucine, lysine, histidine, arginine and tyrosine [24]. Studies developed by Bertolino et al., [17] reported that glutamic acid, valine, leucine, phenylalanine and lysine were the most free amino acids found in hard cheese. Also, Diana et al., [16] performed the amino acid profile in hard cheese, where glycine, leucine, lysine and valine had the highest concentrations. The content of these amino acids from the previous study in the total samples was $99.48,77.87,61.60$ and $52.82 \mathrm{~g} / \mathrm{kg}$, representing $16.2 \%, 12.7 \%$, $10.1 \%$ and $8.62 \%$ respectively. These authors stated that the release of amino acids is significantly influenced by the salt content. On the other hand, when the salt concentration is higher there are less water molecules to interact with the charged part of the protein, and therefore the protein interaction is stronger, releasing the free amino acids. Also the type of rennet that is used influences the final amino acid content, since the cheeses elaborated with artisan rennet have greater concentration of amino acids than the cheeses made with commercial rennet.

The quantification of loss established for the townshipBadillo, it is detailed that the amino acids in general are lost or hydrolyzed in the course of the process, leaving little concentration of them in the cheese. The essential amino acids that are conserved in higher concentration are lysine $91.9 \%$ and tryptophan with $93.19 \%$, and with a greater percentage of loss are isoleucine $98.8 \%$ and leucine with $99.81 \%$. In La Vega, the essential amino acids of the cheese, which had the lowest loss according to the established quantification are methionine with $70.75 \%$ and phenylalanine with $74 \%$ and with higher percentages of loss, isoleucine $98.84 \%$ and leucine with $98.88 \%$, as for the non-essential amino acids with lower percentage of loss is the arginine with $98.64 \%$. Making the quantification of losses in the townshipPatillal, it is observed that the essential amino acid found in the highest concentration in the cheese is tryptophan, followed by valine. The amino acids with the highest loss percentages are isoleucine with $66 \%$ and lysine with $62 \%$.

\section{CONCLUSIONS}

With respect to the results of the municipality of Patillal, this is characterized by being the zone whose essential amino acids predominate in greater proportion after the process of industrialization in comparison with the other townships. On the other hand, the essential amino acids retained in the highest concentration in Badilloquesocosteño are lysine with $91.9 \%$ and tryptophan with $93.19 \%$. Emphasis was placed on milk, whey and cheese from Badillo village, which showed the highest protein content and total solids. It was also possible to show that in these food matrices, there were statistically significant differences in protein content and total solids. Patillal reported the highest protein, fat and lowest ash content in cheese samples.

\section{REFERENCES}

[1] M.H. Boland, A. Singh and A. Thompson,"Milk proteins: from expression to food", Second Edition, Academic Press. United Kingdom, pp. 526-531, 2014.

[2] S.P. Singh,S. Häussler,J.F. Heinz,B. Saremi,B. Mielenz,J. RehageandH. Sauerwein, "Supplementation with conjugated linoleic acids extends the adiponectin deficit during early lactation in dairy cows", General Comp Endocr, 198:13-21.2014.

[3] K. Guzmán, "La industria de lácteos en Valledupar: primera en la región Caribe. Documentos de trabajo sobre Economía Regional", Banco de la República, Centro de Estudios Económicos Regionales (CEER)-Cartagena. Núm. 184. 2013.

[4] D. A. Acevedo,Rodríguez andA. Fernández, "Efecto de las variables de proceso sobre la cinética de acidificación, la viabilidad y la sinéresis del suero costeño colombiano",Inf. Tecnol,vol. 21, no. 2, pp. 29-36, 2010.

[5] P.F. Fox, and P.L. McSweeney,"Cheese: an overview. Cheese: chemistry, physics and microbiology, volume 2, Edited by Patrick F. Fox, Paul L.H. McSweeney, Timothy M. Cogan and Timothy P. Guine 1, pp. 1-18, 2004.

[6] R.A. Parra,"Lactosuero: importancia en la industria de alimentos", Rev. Fac. Nac. Agron. Medellín. Vol. 62, no. 1, pp. 4967-4982, 2009.

[7] R. Rezaei,W.W. Wang,Z.L. Wu,Z. Dai,J. Wang,G. Wu,"Biochemical and physiological bases for utilization of dietary amino acids by young pigs", J AnimSciBiotechnol, vol. 4, no. 7, pp. 1-12, 2013.

[8] A. Abellán, "Caracterización del queso de Murcia al vino. Efecto de la utilización de diferentes coagulantes", Tesis doctoral, Universidad Católica San Antonio, Guadalupe (Murcia), 2010.

[9] M. Popova,V. Bankova,D. Butovska, V.Petkov, B. Nikolova-Damyanova,A.G. Sabatini and A. Bogdanov, "Validated methods for the quantification of biologically active constituents of poplar-type propolis",Phytochem Analysis, vol. 15, no. 4, pp. 235-240, 2004.

[10] B. Redruello,V. Ladero,I. Cuesta,J.R. Álvarez-Buylla,M.C. Martín,M. Fernández,M.A. Alvarez, A fast, reliable, ultra-high performance liquid chromatography method for the simultaneous determination of amino acids, biogenic amines and ammonium ions in cheese, using diethyl ethoxymethylenemalonate as a derivatising agent, Food Chem, vol. 139, no. 1, pp. 1029-1035, 2013.

[11] S.H. Salmen,H.M. Abu-Tarboush, A.A. Al-Saleh and A.A. Metwalli,"Amino acids content and electrophoretic profile of camel milk casein from different camel breeds in Saudi Arabia", Saudi J BiolSci, vol. 19, no. 2, pp. 177-183, 2012.

[12] V.F. Roucher,E. Desnots,C. Naël,A.M. Agnoux,M.C. Alexandre-Gouabau,D. DarmaunandC.Y. Boquien,“Use of UPLC-ESI-MS/MS to quantitate free amino acid concentrations in micro-samples of mammalian milk", SpringerPlus, vol. 2, no. 1, pp. 622, 2013. 
[13] AOAC. Association of Official Analytical Chemistry.Method of Analysis.18th edition.Station, Washington DC, 2005

[14] NTC 399. Instituto Colombiano de Normas Técnicas y Certificación (Colombia), Productos lácteos. Leche cruda. Cuarta actualización, Bogotá, 2002.

[15] Y. López,A. Díaz,L. Vargas,M. Mas,G. Colina,B. SulbaránandJ. Peña,“LeucaenaLeucocephala y AlbiziaLebbeck en el Proceso de Coagulación del Agua", Boletín del Centro de Investigaciones Biológicas, vol. 42, no. 1, pp. 1-20, 2008.

[16] M. Diana,M. Rafecas,C. ArcoandJ. Quílez,"Free amino acid profile of Spanish artisanal cheeses: Importance of gamma-aminobutyric acid (GABA) and ornithine content", J Food Compos Anal, vol. 35, no. 2, pp. 94-100, 2014.

[17] M. Bertolino,P. Dolci,M. Giordano,L. RolleandG. Zeppa,"Evolution of chemico-physical characteristics during manufacture and ripening of Castelmagno PDO cheese in wintertime", Food Chem. Vol. 129, no. 3, pp. 1001-1011, 2011.

[18] M. Addis,G. Piredda,M. Pes,R. Di Salvo,M.F. ScintuandA. Pirisi, "Effect of the use of three different lamb paste rennets on lipolysis of the PDO Pecorino Romano Cheese", Int Dairy J. vol. 15, no. 6, no. 563-569, 2005.

[19] M. Addis,M. Fiori,G. Riu,M. Pes, E. Salvatore andA. Pirisi,"Physico-chemical characteristics and acidic profile of PDO Pecorino Romano cheese: Seasonal variation”, Small Ruminant Res, vol. 126, pp.73-79,2015.

[20] T. Lešić,J. Pleadin,G. Krešić,N. Vahčić,K. Markov,M. Vrdoljak and J. Frece,"Chemical and fatty acid composition of cow and sheep milk cheeses in a lamb skin sack",J Food Compos Anal, vol. 46, pp. 70-77, 2016.

[21] A.T. Mazhitova,A.A. Kulmyrzaev,Z.E. OzbekovaandA. Bodoshev,"Amino Acid and Fatty Acid Profile of the Mare's Milk Produced on Suusamyr Pastures of the Kyrgyz Republic During Lactation Period",ProcediaSocBehavSci, vol. 195, pp. 2683-2688, 2015.

[22] E.C. Pappaand K. Sotirakoglou,"Changes of free amino acid content of Teleme cheese made with different types of milk and culture",FoodChem, vol. 111, no. 3, pp. 606-615, 2008.

[23] J. Calzada, Prevención de la sobremaduración y de la formación de aminas biógenas en quesos mediante tratamientos de altas presiones. Tesis Doctoral. Universidad Complutense de Madrid. Facultad de Veterinaria, 2015.

[24] R. Benítez,A. IbarzandJ. Pagan, “Hidrolizados de proteína: procesos y aplicaciones”, Acta bioquím. clín. Latinoam, vol. 42, no. 2, pp. $227-236,2008$ 